\begin{tabular}{c|c|c}
\hline \hline Vol. 2: 1-15, 2008 & AQUATIC BIOLOGY & Printed April 2008 \\
doi: $10.3354 / \mathrm{ab} 00031$ & Aquat Biol & Published online February 7, 2008
\end{tabular}

\title{
Mussel histopathology: effects of season, disease and species
}

\author{
J. P. Bignell, M. J. Dodge, S. W. Feist, B. Lyons, P. D. Martin, N. G. H. Taylor, \\ D. Stone, L. Travalent, G. D. Stentiford*
}

Centre for Environment, Fisheries and Aquaculture Science (Cefas), Barrack Road, Weymouth, Dorset DT4 8UB, UK

\begin{abstract}
We assessed seasonal histological changes as markers of health status in mussels Mytilus spp. sampled from Southampton Water, Hampshire, UK and the River Exe, Devon, UK between November 2004 and October 2005. A total of 29 health parameters related to pathogens, inflammatory and non-specific pathologies, and reproductive and physiological condition were recorded monthly from individual mussels collected from these 2 sites. We then assessed the diffential prevalence of these health parameters according to species. M. edulis, M. galloprovincialis and their hybrids were identified using the Glu-5' gene and the ME15 and ME16 primer sets that distinguish alleles specific to $M$. edulis (180 bp), M. galloprovincialis (126 bp) and hybrids (180 bp/126 bp). Although no overall annual differences were observed between species with respect to median levels of adipogranular (ADG) tissue and reproductive status, specific differences in reproductive status were observed within individual months. During these months (August to October), M. edulis exhibited a relatively lower reproductive status compared to M. galloprovincialis and hybrids. With respect to all remaining health parameters (pathogens, inflammatory and non-specific pathology), principal components analysis revealed no overall differences between species throughout the year. However, greater differences were observed between species during the autumn and winter than during the spring and summer, thus indicating that species differences may be exacerbated by season. This study highlights how species can affect the accurate interpretation of histopathology data collected during biological effects monitoring programmes. Whether species can also affect the biomarker response of Mytilus mussels to contaminated environments remains to be shown. The results are discussed in the context of biological effects monitoring utilising mussels.
\end{abstract}

KEY WORDS: Histopathology · Biological effects · Mytilus edulis · Mytilus galloprovincialis $\cdot$ Hybrids · Disease $\cdot$ Mussel $\cdot$ Seasonality $\cdot$ Species

Resale or republication not permitted without written consent of the publisher

\section{INTRODUCTION}

Mussels (Mytilus spp.) have been utilised in biological effects monitoring programmes to assess the effects of exposure to aquatic contaminants for many years (Bayne 1976, Goldberg et al. 1978, Widdows \& Donkin 1992, Granmo 1995, Salazar \& Salazar 1995). Mussels are ubiquitous and are known to exhibit a range of biological responses when exposed to contaminants (Goldberg et al. 1978, Rasmussen 1982, Calabrese et al. 1984, Akberali et al. 1985, O'Connor 1998, Widdows et al. 2002). As such, mussels have been suggested as a sentinel for use in contaminant and biological effects monitoring programmes and offer con-

*Corresponding author. Email: grant.stentiford@cefas.co.uk

$\S_{\text {Corrections }}$ were made after publication. For details see www.int-res.com/abstracts/ab/v2/n1/c_p1-15/

This corrected version: March 8, 2019 siderable potential for comparison of international data on the health status of our seas and oceans. The 'Mussel Watch' programme initiated in 1976 selected various shellfish species, including mussels, as potential sentinels for the underlying contaminant status of US coastal waters (Goldberg et al. 1978). The parameters examined included synthetic chlorinated compounds, polychlorinated biphenyls (PCBs), polycyclic aromatic hydrocarbons (PAHs), radionuclides and trace metals. Mussel Watch and the similar programmes that followed were primarily directed towards measurement of contaminant concentrations, with relatively little emphasis on the biological consequences of exposure to these contaminants (Goldberg \& Bertine 2000). Sub- 
sequently, numerous recommendations have emerged which promote the use of biomarkers of exposure to, and effects of, contaminants (Moore et al. 1987, Moore 1990, Galloway et al. 2002).

Histopathology (of aquatic organisms) is a valuable tool for providing health assessments of individuals and of populations since it incorporates measures of reproductive and metabolic condition, and allows for the detection of a range of pathogens that may affect morbidity and mortality. In addition to its role in providing a 'baseline' measure of health, histopathology has been employed to investigate the changes related to $\mathrm{PAH}, \mathrm{PCB}$ and heavy metal exposure in mussels (Sunila 1984, Lowe \& Pipe 1987, Auffret 1988, Kluytmans et al. 1988, Marigómez et al. 2006). However, since histopathology has also been used to investigate the effects of disease and parasite infestation in wild mussel populations (Rasmussen 1986, Davey 1989, Figueras et al. 1991, Robledo et al. 1994, Powell et al. 1999, Svärdh 1999), care must be taken when using histopathology as a biomarker of contaminant exposure per se. In this respect, histopathology can be considered as a means to provide supporting information for measures (biomarkers) that specifically aim to assess historic exposure to, or effect of, a contaminant. Histopathology therefore provides a 'phenotypic anchor' against which this specific data can be assessed (Stentiford et al. 2005, Hines et al. 2007a).

The advent of genomic and post-genomic technologies increases the potential utility of histopathology in quality assurance and quality control of sample groups for analysis (e.g. by selecting homogenous group attributes and to control for potential variation amongst individuals). This approach should help reduce uncertainties associated with the potential confounding effects of pathogens when trying to identify the specific effects of toxicant exposure on host gene, protein and metabolite profiles (Stentiford et al. 2005, Ward et al. 2006, Hines et al. 2007a). Because mussels are relatively sessile, relatively abundant and have a tendency to react rapidly to their environment, they are likely to be used increasingly in biological effects monitoring programmes. Furthermore, genomic and post-genomic technologies are already beginning to be applied to mussels in field and laboratory settings (Shepard et al. 2000, Viant et al. 2003, Olsson et al. 2004, Rosenblum et al. 2005, 2006, Hines et al. 2007a,b).

We examined the seasonal variation in the prevalence of numerous health parameters in Mytilus edulis, M. galloprovincialis and their hybrids from 2 different estuarine environments in the UK. Monthly sampling was carried out over a 12 mo period on the River Exe estuary in Devon and at Southampton Water, Hampshire. The Exe estuary is situated within a relatively rural area $56 \mathrm{~km}$ distant from a previously docu- mented mussel hybrid zone in southwest England (Skibinski et al. 1983, Hilbish et al. 2002). The mussels inhabiting the Exe estuary have been identified to be of the species M. edulis (Hilbish et al. 2002). Southampton Water is situated within a relatively urbanised area approximately $169 \mathrm{~km}$ distant from the southwest England hybrid zone. It is subject to significant levels of water traffic related to its numerous docks, marinas and shipyards. Previous work undertaken by the Department for Environment, Food and Rural Affairs (J. P. Bignell unpubl. data) has demonstrated that a population of $M$. edulis, M. galloprovincialis and their hybrids inhabit Southampton Water. We provide baseline data on numerous health parameters in mussels sampled over a 12 mo period from the 2 sites. Incorporation of species data has enabled an investigation of the potential for genotype to influence these parameters. We think that our results support the simultaneous collection of data pertaining to health, species and biomarkers in chemical and biological effects monitoring programmes.

\section{MATERIALS AND METHODS}

Sampling. Mussels were collected randomly from fixed sampling sites, once per month over the 12 mo period between November 2004 and October 2005. Sampling sites were Cracknore Hard in Southampton Water, Hampshire, UK (5053.64' N, 01 25.28' W) and Starcross on the River Exe estuary, Devon, UK $\left(50^{\circ} 37.61^{\prime} \mathrm{N}, 03^{\circ} 26.73^{\prime} \mathrm{W}\right)$. For sampling, 50 mussels (length range 4 to $7 \mathrm{~cm}$ ) were collected from the waterline at low tide. Background data for salinity and temperature were also measured using a refractometer and thermometer respectively. Mussels were transferred immediately into $\sim 151$ of estuarine water collected from the sampling location and kept cool in an insulated sealed container for transit to the laboratory (maximum transit time $2 \mathrm{~h}$ ). This was undertaken in order to limit any histological artefacts that may result from the sampling and transport process (Dimitriadis \& Koukouzika 2003). For dissection, shells were opened by severance of the adductor muscle followed by removal of the tissue mass. Samples of gill were taken, snap frozen in liquid nitrogen and subsequently processed for species identification (see 'Materials and methods-Species identification' below). A 3 to $4 \mathrm{~mm}$ cross-section was removed along a standard plane that allowed for all major organs and tissues (gill, mantle, kidney, digestive gland, gonad and byssus gland/foot) to be incorporated into a single histological section. A sample of adductor muscle was also obtained. All tissues were processed for histology as described in 'Materials and methods-Histology' below. 
Species identification. Total DNA was extracted from $100 \mu \mathrm{l}$ of a 1:10 dilution of gill tissue homogenate in transport media containing penicillin $\left(200\right.$ units $\left.^{-1}\right)$, streptomycin $\left(0.2 \mathrm{mg} \mathrm{ml}^{-1}\right)$, amphotericin B $\left(0.25 \mathrm{\mu g} \mathrm{ml}^{-1}\right)$ and new-born calf serum $(10 \%)$ in $1 \mathrm{ml}$ of DNAzol ${ }^{\circledR}$ reagent following the manufacturer's recommended protocol (Invitrogen). The pellet was suspended in $100 \mu \mathrm{l}$ of molecular-grade water. A $180 \mathrm{bp}$ segment for Mytilus edulis and $126 \mathrm{bp}$ for M. galloprovincialis of the Glu gene were amplified by PCR using sense primer Me15 5'-CCAGTATACAAACCTGTGAAGA-3' and anti-sense primer Me16 5'-TGTTGTCTTAATAG GTTTGTAAGA-3' (Inoue et al. 1995). PCR was performed in a $50 \mu \mathrm{l}$ reaction volume consisting of $1 \times$ GoTaq $^{\circledR}$ flexi buffer containing $2.5 \mu \mathrm{\mu l}$ template $2.5 \mathrm{mM} \mathrm{MgCl} 2,1 \mathrm{mM}$ deoxyribonucleotide phosphates (dNTPs) mix, $100 \mathrm{pmol}$ of sense and anti-sense primers, 2.5 units of GoTaq polymerase (Promega). The reaction mix was overlaid with mineral oil and after pre-heating to $95^{\circ} \mathrm{C}$ for $5 \mathrm{~min}$, subjected to 35 temperature cycles of: $1 \mathrm{~min}$ at $95^{\circ} \mathrm{C}, 1 \mathrm{~min}$ at $55^{\circ} \mathrm{C}$ and $1 \mathrm{~min}$ at $72^{\circ} \mathrm{C}$ followed by a final extension step of $10 \mathrm{~min}$ at $72^{\circ} \mathrm{C}$. Twenty $\mu \mathrm{l}$ of amplified products were electrophoresed in a $4 \%$ (w/v) agarose/TAE (40 mM Tris-acetate, $\mathrm{pH} 7.2,1 \mathrm{mM}$ EDTA) gel containing $1.0 \mu \mathrm{g} \mathrm{ml}^{-1}$ ethidium bromide and visualised under UV irradiation (Fig. 1).

Histology. Excised samples were placed into histological cassettes and immediately transferred to Davidson's seawater fixative. Fixation was allowed to proceed for $24 \mathrm{~h}$ before transfer of fixed samples to $70 \%$ industrial methylated spirit until further processing. Samples were processed in a Vision Bio-Systems Peloris vacuum infiltration processor followed by embedding in paraffin wax. Thin sections (3 to $5 \mu \mathrm{m})$ were obtained using a rotary microtome and subsequently stained with haematoxylin and eosin. Sections were

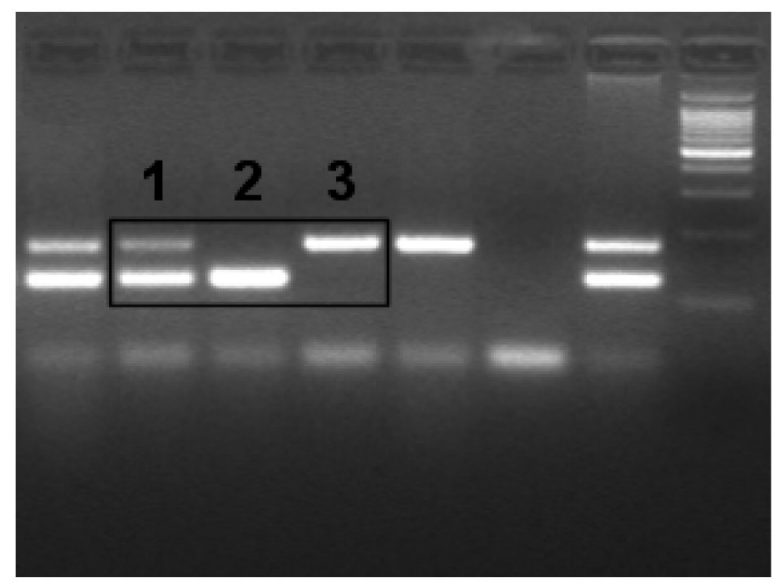

Fig. 1. Mytilus spp. Representative photograph of electrophoresis $4 \%$ agarose gel showing bands for (1) hybrid mussels, 126 and $180 \mathrm{bp}$; (2) M. edulis, $180 \mathrm{bp}$; and (3) M. galloprovincialis, $126 \mathrm{bp}$ evaluated 'blind' for 29 health parameters (Table 1) in relation to site, season and species. Assessment of adipogranular (ADG) tissue was carried out using the grading system outlined in Table 2. Gonadal development staging was carried out as described by Seed (1976). All micrographs were captured using a Nikon DXM1200F digital video camera and the Lim Screen Measurement ${ }^{\mathrm{TM}}$ Lucia G image capture system (Nikon UK).

Statistical analysis. Statistical analysis of median gonad development state and ADG staging index was conducted by ordinal logistic regression (OR) using a logit link function in Minitab v.13.2, then, models were fitted and assessed (Minitab). Principal components analysis (PCA) was conducted using Multi-Variate Statistical Package (MVSP) v.3.13n (Kovach Computing Services) to determine relative similarity of pathologies and parasites observed in mussels of each species at different time points. Since mussel populations at the Exe estuary site were solely comprised of Mytilus edulis, inter-species comparisons were only possible on mussels collected from Southampton Water.

\section{RESULTS}

\section{Species identification}

PCR products were obtained for 1182 of the 1200 ind. analysed. All mussels from the Exe estuary were identified as Mytilus edulis, thus, confirming a pure population as previously described by Hilbish et al. (2002). Species identification of Southampton Water mussels revealed a mixed species population of $M$. edulis, $M$. galloprovincialis and their hybrids. Generally, M. galloprovincialis and hybrids made up the majority of the population with small numbers of $M$. edulis being obtained in most months (Table 3). M. edulis generally represented the smallest percentage of the population ( 4 to $54 \%$ over the 12 mo sampling period). The highest numbers of $M$. edulis were obtained during May. M. galloprovincialis represented 16 to $78 \%$, and hybrids 14 to $52 \%$ of the population. These species differences observed between months were most probably associated with random sampling error as a result of the relatively small samples sizes used each month.

\section{Health parameters}

A total of 29 health index parameters were recorded from individual mussels in each of the sampling periods. Health parameters included those related to pathogen or parasite infections, inflammatory and non-specific pathologies, and those associated with 
reproductive or physiological condition. These health parameters are listed in Table 1 with representative micrographs in Figs. 2, 3 \& 4 .

\section{Pathogens and parasites}

The prevalence and severity of many parameters showed fluctuations throughout the sampling period. Several parasites were commonly observed infecting mussels during this study. Mytilicola intestinalis, a parasitic copepod (Fig. 2a), was most prevalent in Mytilus edulis collected from Exe estuary during November $(65.0 \%)$. A parasitic copepod of the gills was also observed in individuals from both sites (Fig. 2b) at relatively low prevalence. Ancistrum mytili and similar gill ciliates were observed in each month of the study (Fig. 2c) with the prevalence being highest during the summer months. A similar pattern of increased summer prevalence of $A$. mytili was observed in mussels collected from both Exe estuary and Southampton Water although prevalence was generally higher at Exe estuary in all seasons. Encysted digenean metacercaria (Fig. 2d) were observed at relatively higher prevalence in mussels from Exe estuary $(23.0$ to $71.0 \%)$ than in those from Southampton Water $(4.0$ to $14.0 \%)$, with highest prevalence during the winter months. Several parasites were observed at relatively low prevalence during certain months; notably the paramyxum Marteilia sp. within the digestive epithelial cells of the digestive diverticula observed affecting a single mussel from Southampton Water in June (Fig. 2e). Immature stages were also observed within the gut epithelium. A microsporidian parasite, Steinhausia mytilovum, was observed in the oocytes of 1 mussel from Southampton Water in September (Fig. 2f). To the best of our knowledge these are the first descriptions of Marteilia sp. and S. mytilovum infections in mussels from UK waters. A haplosporidian infection (Fig. 3a) was observed in mussels from Southampton Water at relatively low prevalence during December, August, September and October (2.1 to $6.3 \%$ ) and in mussels from Exe estuary during September and October (2.0 and $6.0 \%$, respectively). A bucephalid infection of the vesicular connective tissue was seen in mussels from Southampton Water during December, July, September and October (2.0 to $4.0 \%$ ) and from Exe estuary during September (2.0\%). Interestingly, the adductor muscle of 1 individual was also infected (Fig. 3b). To the best of our knowledge, this is the first report of a bucephalid infecting the adductor muscle.

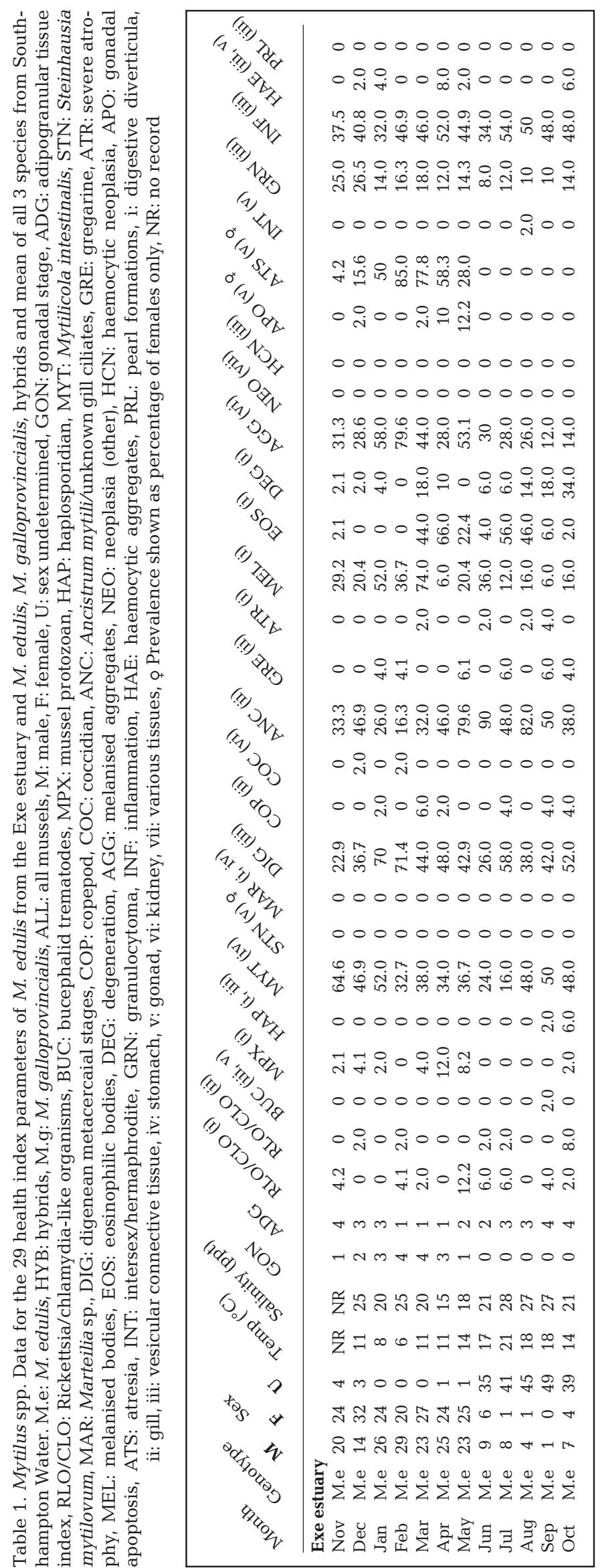




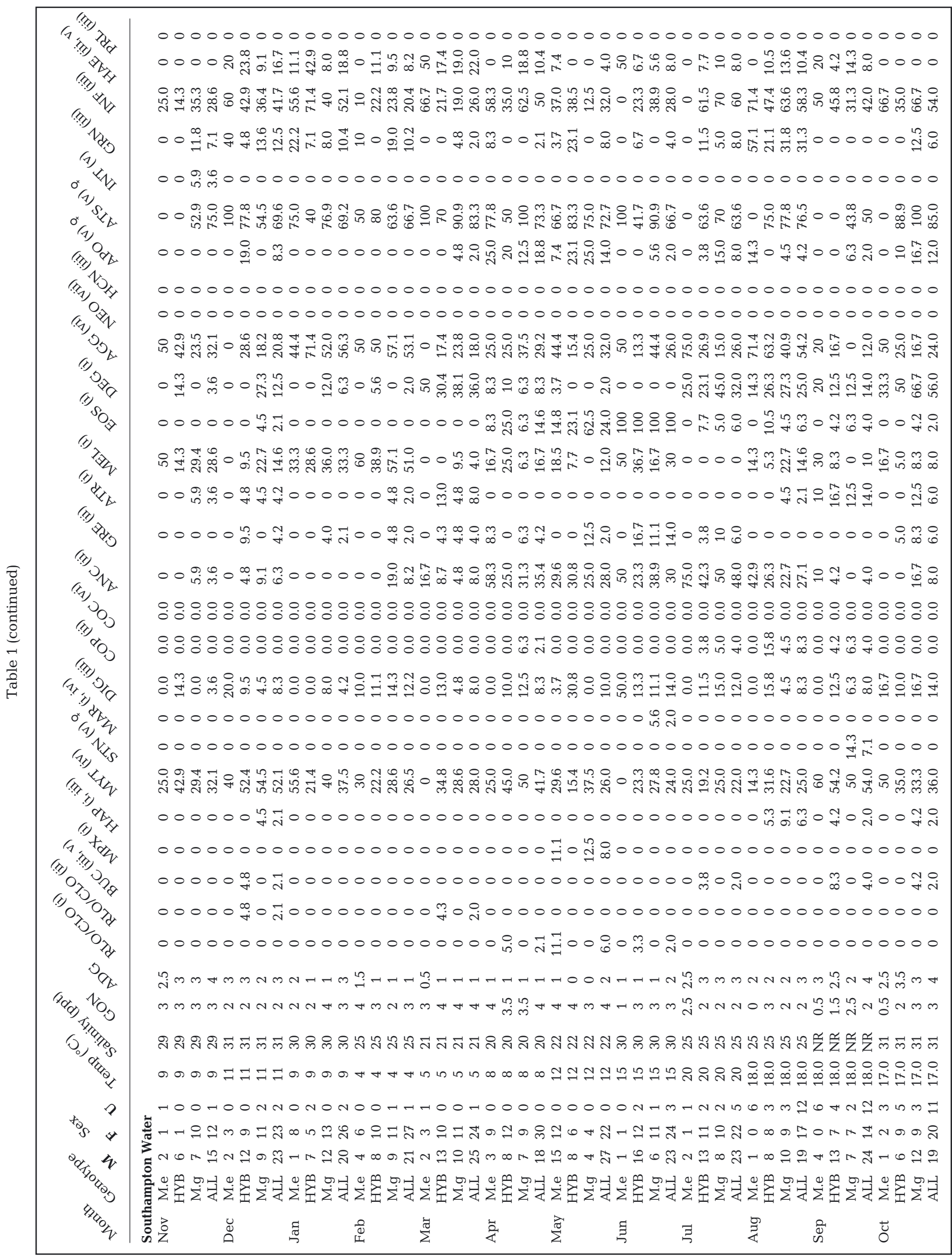


Table 2. Mytilus spp. Adipogranular (ADG) tissue scoring index

\begin{tabular}{|c|c|c|}
\hline Stage & Score & Description \\
\hline 0 & Absent & $\begin{array}{l}\text { No ADG cells apparent within vesi- } \\
\text { cular connective tissue }\end{array}$ \\
\hline 1 & Present & $\begin{array}{l}\text { Although ADG cells can be seen, they } \\
\text { appear to be scarce }\end{array}$ \\
\hline 2 & Scattered & $\begin{array}{l}\text { ADG cells appear scattered through- } \\
\text { out mantle tissue }\end{array}$ \\
\hline 3 & Frequent & $\begin{array}{l}\text { There is a marked increase in the } \\
\text { abundance of ADG cells. Some areas } \\
\text { may not appear to show absolute } \\
\text { consistency }\end{array}$ \\
\hline 4 & Abundant & $\begin{array}{l}\text { ADG cells can be seen to constitute the } \\
\text { majority of connective tissue volume }\end{array}$ \\
\hline
\end{tabular}

Inflammatory and non-specific pathology

Inflammation of the connective tissue was observed at varying prevalence (0 to $70.0 \%$ ) in all mussel species sampled throughout the year from both sites. Lesions appeared as either diffuse haemocytic infiltration of the vesicular connective tissue or as discrete focal accumulations that displaced connective tissues and organ systems. Inflammation was occasionally associated with infestation by Marteilia sp., Steinhausia mytilovum or digenean metacercariae. Severe inflammation was often accompanied by an increased prevalence of granulocytomas (either as single or multiple lesions) within the connective tissues (Fig. 3c). Such lesions often replaced significant proportions of the space normally occupied by the vesicular connective tissue and digestive diverticula. The seasonal prevalence of granulocytomas appeared to approximate the prevalence of inflammation (albeit at a lower prevalence) in mussels sampled from both sites. Another inflammatory lesion, melanised haemocyte aggregates, were observed within the testicular follicles of some male mussels (Fig. 3d) and appeared to be more prevalent between December and April; and less prevalent from May to November for both sampling sites. Similar aggregations were often seen in the digestive diverticula epithelium, connective tissues, gills and within the gut wall. Degeneration of the digestive diverticula was characterised by disintegration and subsequent absence of digestive cells and pyramidal basophilic secretory cells within the digestive epithelia. In advanced stages, only the basement membrane remained with detached cells presumably passing to the tubule lumen for exit via the gut. Cellular debris was often observed within the lumen of digestive tubules (Fig. 3e). Melanised kidney aggregates (Fig. 3f) were often observed within the kidney epithelium at varying severities. Their prevalence ranged from 12.0 to $79.6 \%$ in mussels from Exe estuary and 12.0 to $56.3 \%$ in those from Southampton Water. The highest prevalence was observed in January and February at both sites.

An unidentified condition, characterised by the presence of eosinophilic bodies within the digestive cells of the digestive diverticula was observed in mussels from both sites (Fig. 4a). These bodies appeared in varying shapes, sizes and frequency, sometimes with many occupying the entire cytoplasm of the digestive cells. Those individuals with the highest frequency of bodies expelled a red liquid from their digestive diverticula and stomach upon dissection. The highest prevalence was recorded in April (66.0\%) and in June (100.0\%) for mussels from the Exe estuary and Southampton Water, respectively. Eosinophilic bodies were not seen within the basophil cells of the digestive epithelium.

\section{Reproductive and physiological condition}

For assessment of the reproductive condition of individual mussels, ADG cell status (Fig. 3f) and gonadal status were measured in all mussels sampled throughout the study. Assessment of ADG rate using the scoring index (Table 2) revealed subtle differences between mussels collected from the Exe estuary and those from Southampton Water. The median ADG rate in Exe estuary mussels was highest during September followed by a decline to lowest

Table 3. Mytilus spp. Species distribution (n) of M. edulis, M. galloprovincialis and hybrids throughout the sampling period from the Exe estuary and Southampton Water

\begin{tabular}{|c|c|c|c|c|c|c|c|c|c|c|c|c|}
\hline \multirow[t]{2}{*}{ Species } & \multicolumn{12}{|c|}{ Distribution (n) } \\
\hline & Nov & Dec & Jan & Feb & Mar & Apr & May & Jun & Jul & Aug & Sep & Oct \\
\hline \multicolumn{13}{|l|}{ Exe estuary } \\
\hline M.edulis & 48 & 49 & 50 & 49 & 50 & 50 & 49 & 50 & 50 & 50 & 50 & 50 \\
\hline \multicolumn{13}{|l|}{ Southampton Water } \\
\hline M.edulis & 4 & 5 & 9 & 10 & 6 & 12 & 27 & 2 & 4 & 7 & 10 & 6 \\
\hline M.galloprovincialis & 17 & 22 & 25 & 21 & 21 & 16 & 8 & 18 & 11 & 22 & 16 & 24 \\
\hline Hybrid & 7 & 21 & 14 & 18 & 23 & 20 & 14 & 30 & 26 & 19 & 24 & 20 \\
\hline
\end{tabular}



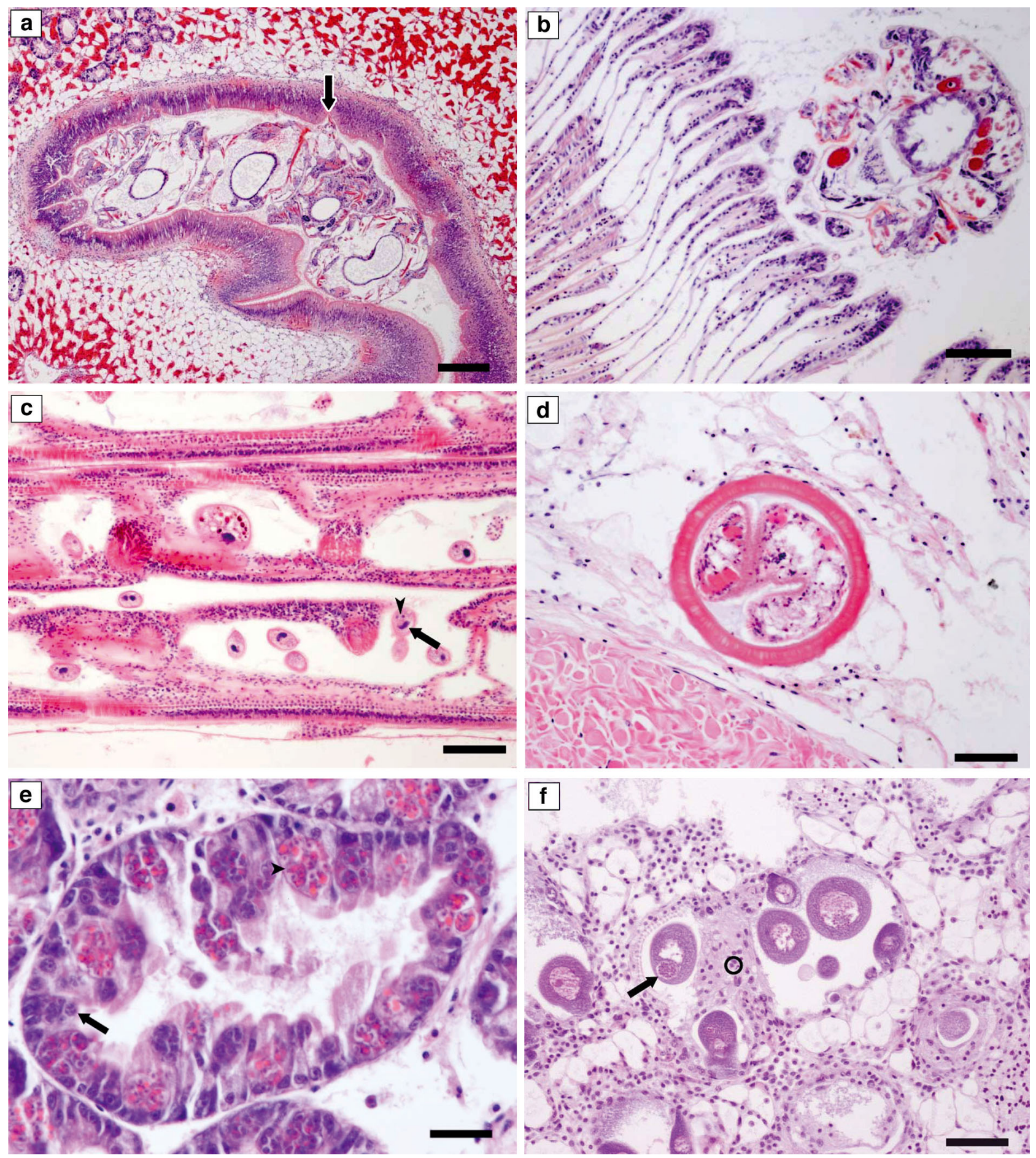

Fig. 2. Mytilus spp. Histopathology. (a) Mytilicola intestinalis. Arrow shows 1 of $5 \mathrm{M}$. intestinalis copepods that were visible attached to gut epithelium using hook-like appendages. Scale bar: $200 \mu \mathrm{m}$. (b) Unidentified copepod attached to secondary gill lamellae. Scale bar: $100 \mu \mathrm{m}$. (c) Ancistrum mytili attached to gill lamellae. Note presence of pear-shaped body, single large macronucleus (arrow) and 2 micronuclei (arrowhead). Parasite did not appear to elicit a host response. Scale bar: $100 \mu \mathrm{m}$. (d) Individual metacercarial stage of an unidentified digenean parasite encapsulated with a pearl formation. Scale bar: $50 \mu \mathrm{m}$. (e) Marteiliosis. Eosinophilic 'cell-within-cell' sporocysts clearly identified within the epithelium of the digestive diverticula (arrowhead). Earlier developmental stages (arrow). Scale bar: $25 \mu \mathrm{m}$. (f) Steinhausia mytilovum. Sporocysts containing many spores residing in the cytoplasm of oocytes (arrow). Haemocytic infiltration visible within gonadal follicles (O) and surrounding connective 

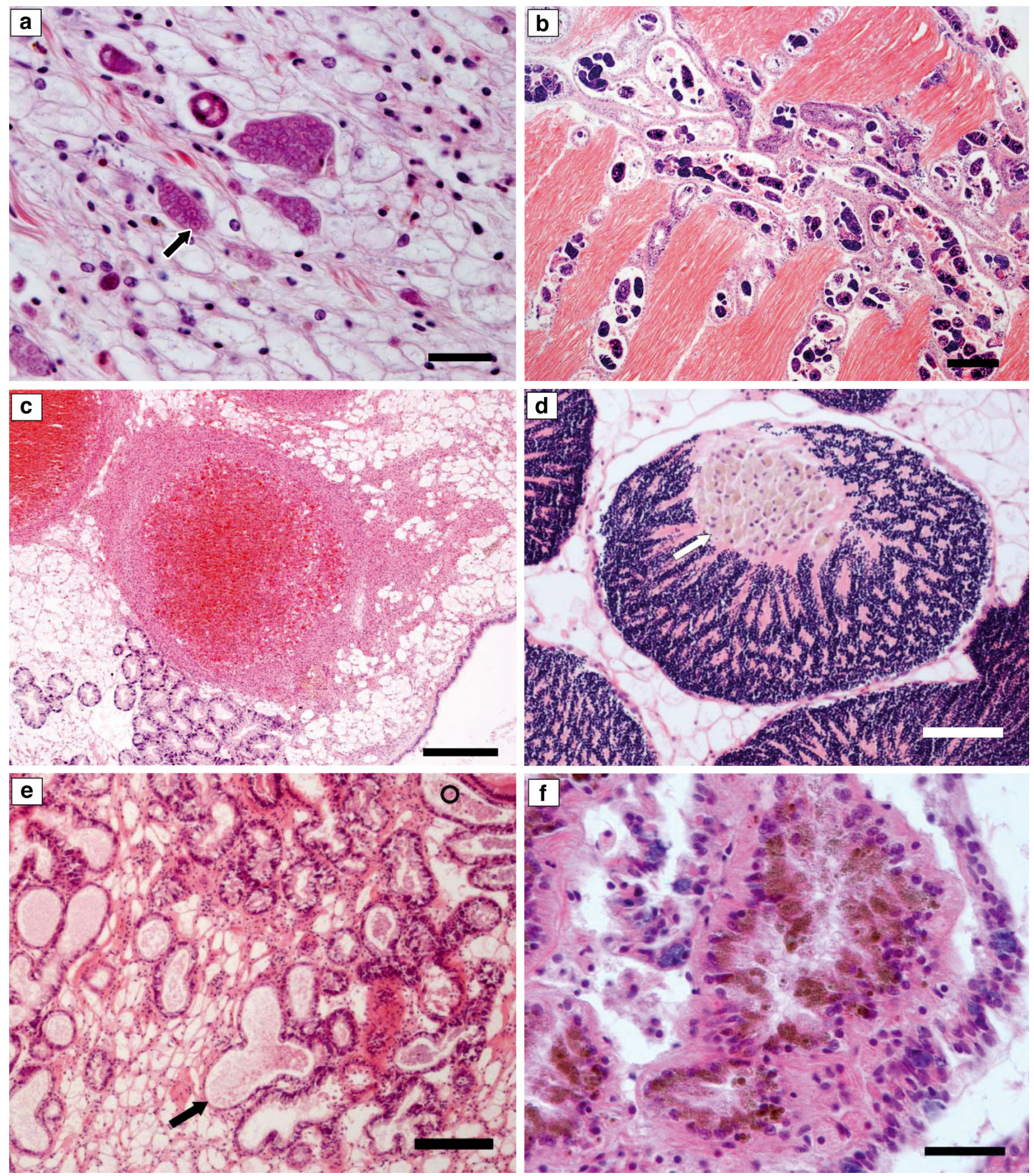

Fig. 3. Mytilus spp. Histopathology. (a) Haplosporidian infection showing multinucleated plasmodia (arrow) within vesicular connective tissue. Scale bar: $25 \mu \mathrm{m}$. (b) Sporocysts containing many individual developing Bucephalid cercariae within anterior adductor muscle. Scale bar: $100 \mu \mathrm{m}$. (c) Large granulocytoma within the vesicular connective tissue surrounding the digestive diverticula. Such lesions contained relatively large amorphous eosinophilic granulocytes. Note aggregating haemocytes at the periphery of the lesion. Scale bar: $300 \mu \mathrm{m}$. (d) Haemocytic aggregate within the testicular follicle. Note melanised appearance of the haemocytes (arrow). Scale bar: $25 \mu \mathrm{m}$. (e) Degeneration of the digestive diverticula epithelium. Cellular debris are visible within the lumen of digestive tubules (O). In advanced stages, only the basement membrane remained (arrow). Scale bar: $100 \mu \mathrm{m}$. (f) Kidney epithelial cells containing fine particular melanin deposits within the cytoplasm. Scale bar: $25 \mu \mathrm{m}$ 

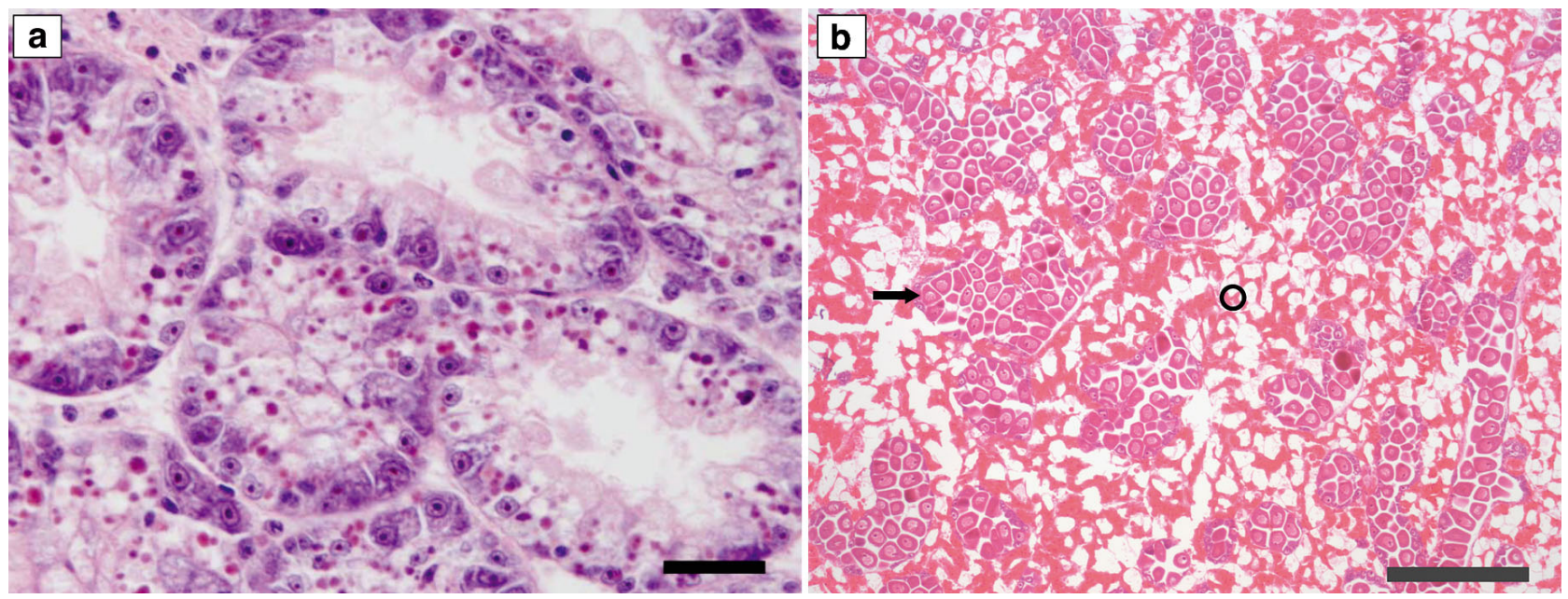

Fig. 4. Mytilus spp. Histopathology. (a) Unidentified eosinophilic bodies residing in digestive cells of the digestive diverticula. Scale bar: $25 \mu \mathrm{m}$. (b) Representative image of mantle tissue showing adipogranular and vesicular connective tissue (O). Gonadal follicles containing oocytes can be seen dispersed throughout the mantle (arrow). Scale bar: $300 \mu \mathrm{m}$

levels between February and April (Fig. 5). An increase in the ADG rate followed the nadir, reaching maximal levels once again in the following September. Although broadly following a similar pattern, the median ADG rate for the 3 mussel species sampled from Southampton Water appeared to fluctuate during the sampling period (Fig. 6) when compared to the pure $M$. edulis population sampled from Exe estuary. The median gonadal stage of mussels from Exe estuary was highest in February and March (Fig. 7) followed by a decrease during the spawning period. The lowest maturation levels were recorded between June and October. The median gonadal stage of mussels from Southampton Water displayed a different pattern with fluctuations observed in particular months, invariably between species (Fig. 8).

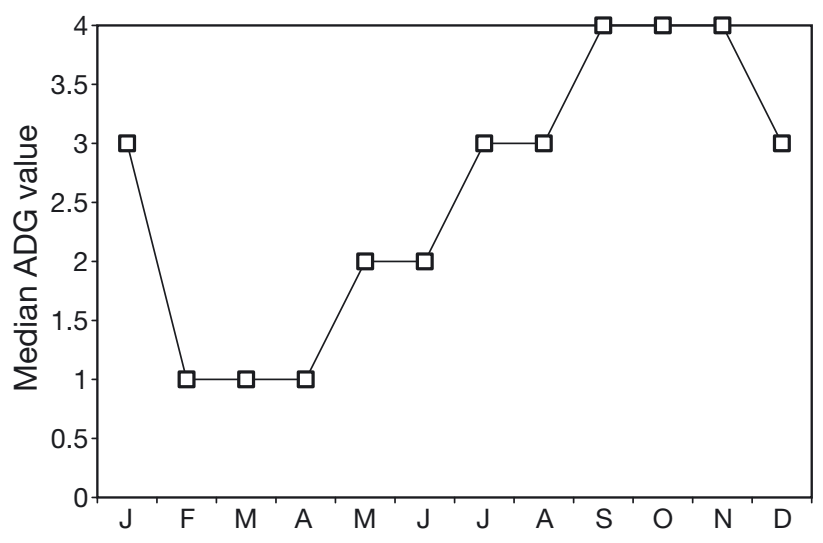

Fig. 5. Mytilus edulis. Median adipogranular (ADG) rate of blue mussels from the Exe estuary

\section{Effect of species on health parameters at Southampton Water}

Plots of median ADG values for Mytilus edulis, M. galloprovincialis and their hybrids over time revealed no obvious differences between species (Fig. 6), but did show a clear seasonal pattern for each. ADG rate was highest from July to December, and lowest from January to June. Ordinal logistical regression showed that the probability of hybrids having higher ADG rate compared to $M$. edulis were significantly greater in October and November $(\mathrm{OR}=20, \mathrm{p}=0.007$ and $\mathrm{OR}=20, \mathrm{p}=0.033)$. Overall, the analysis suggested that the probability of $M$. edulis having a high ADG rate was greater than for hybrids $(\mathrm{OR}=6.14, \mathrm{p}=0.02)$.

In terms of gonadal status, there appeared to be a seasonal change in Mytilus edulis, M. galloprovincialis

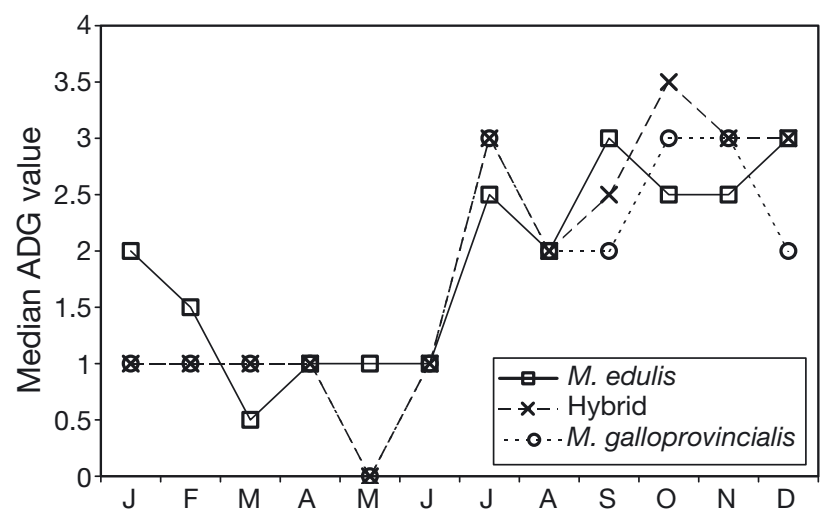

Fig. 6. Mytilus spp. Median ADG rate of M. edulis, M. galloprovincialis and hybrids from Southampton Water 


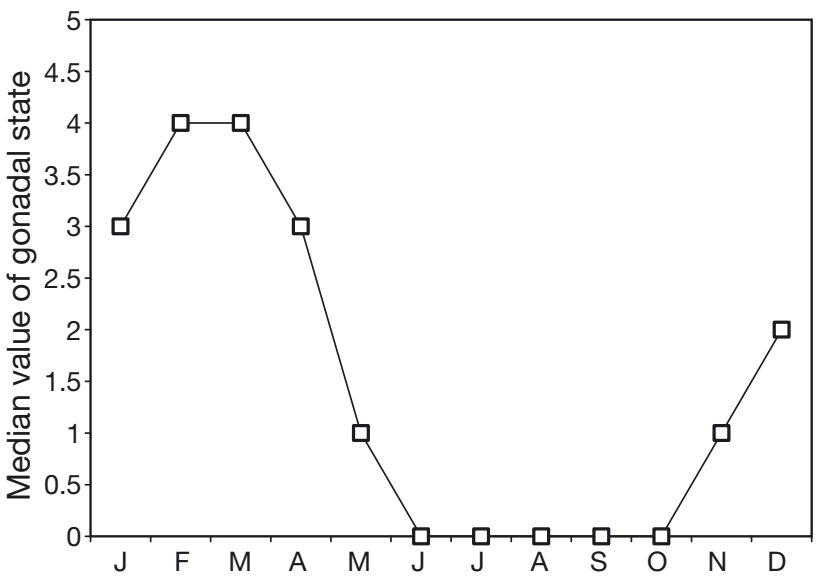

Fig. 7. Mytilus edulis. Median gonadal status of M. edulis from the Exe estuary

and their hybrids from Southampton Water (Fig. 8), although it was less obvious than that observed for ADG rate. The pattern was opposite to that of ADG, with gonadal tissue being less developed from June to October than from November to May. The pattern between M. galloprovincialis and hybrid mussels appeared similar, with relatively little seasonal variation. M. edulis however, showed a more pronounced seasonality in gonadal status, especially in the summer months when development was lower than M. galloprovincialis and hybrids. Ordinal logistic regression revealed no overall differences when the effect of time was held constant. However, the same test did reveal that the probability of hybrids being reproductively more mature than $M$. edulis was significantly higher in August, September and October $(\mathrm{OR}=100, \mathrm{p}<0.001 ; \mathrm{OR}=11.11$, $\mathrm{p}=0.023$ and $\mathrm{OR}=10, \mathrm{p}=0.042$, respectively), and was significantly higher than in $M$. galloprovincialis in May $(\mathrm{OR}=21.69, \mathrm{p}=0.002)$. The probability of $M$. edulis having more developed gonadal tissue than M. galloprovincialis was significantly higher in February, April and May $(\mathrm{OR}=27.49, \mathrm{p}=0.001$; $\mathrm{OR}=7.01, \mathrm{p}=0.05$ and $\mathrm{OR}=22.04, \mathrm{p}=$ 0.002 respectively), but was significantly lower in August $(\mathrm{OR}=16.67, \mathrm{p}=0.03)$.

PCA was performed on 25 health parameters (omitting ADG rate and gonadal status) affecting both sexes and 36 species groups (12 mo, 3 species $\mathrm{mo}^{-1}$ ). This was used to summarise the prevalence of parasites and pathologies noted in Mytilus edulis, M. galloprovincialis and their hybrids throughout the

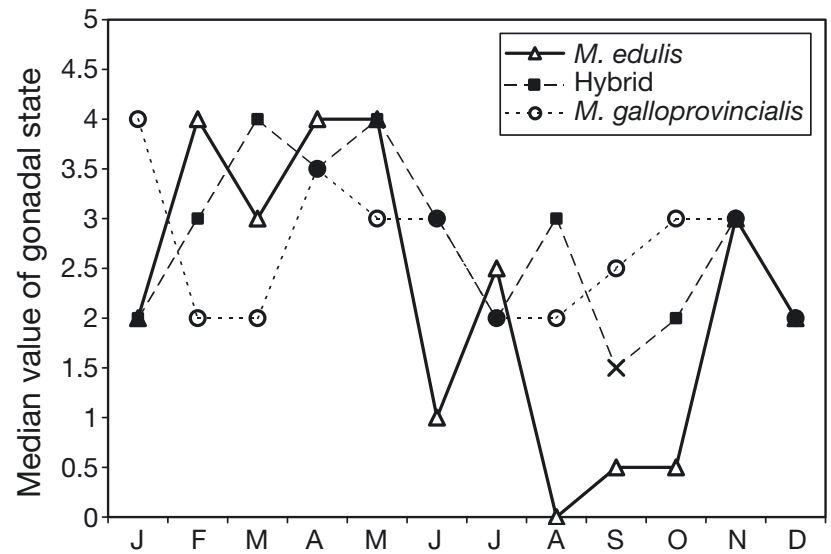

Fig. 8. Mytilus spp. Median gonadal status of $M$. edulis, M. galloprovincialis and hybrids from Southampton Water

study year. Components 1 and 2 explained a total of $42 \%$ of the variability in the dataset $(27$ and $15 \%$ respectively). Results of the analysis revealed variation in the pathology and parasites present between months. Fig. 9 shows that in most months, similar pathologies and parasites were observed between $M$. edulis, M. galloprovincialis and hybrids. However, in some months (February, October, November and December), considerable differences between them were observed. In each of these months, apart from December, the parasites in M. galloprovincialis showed a weaker negative association with Component 1 than

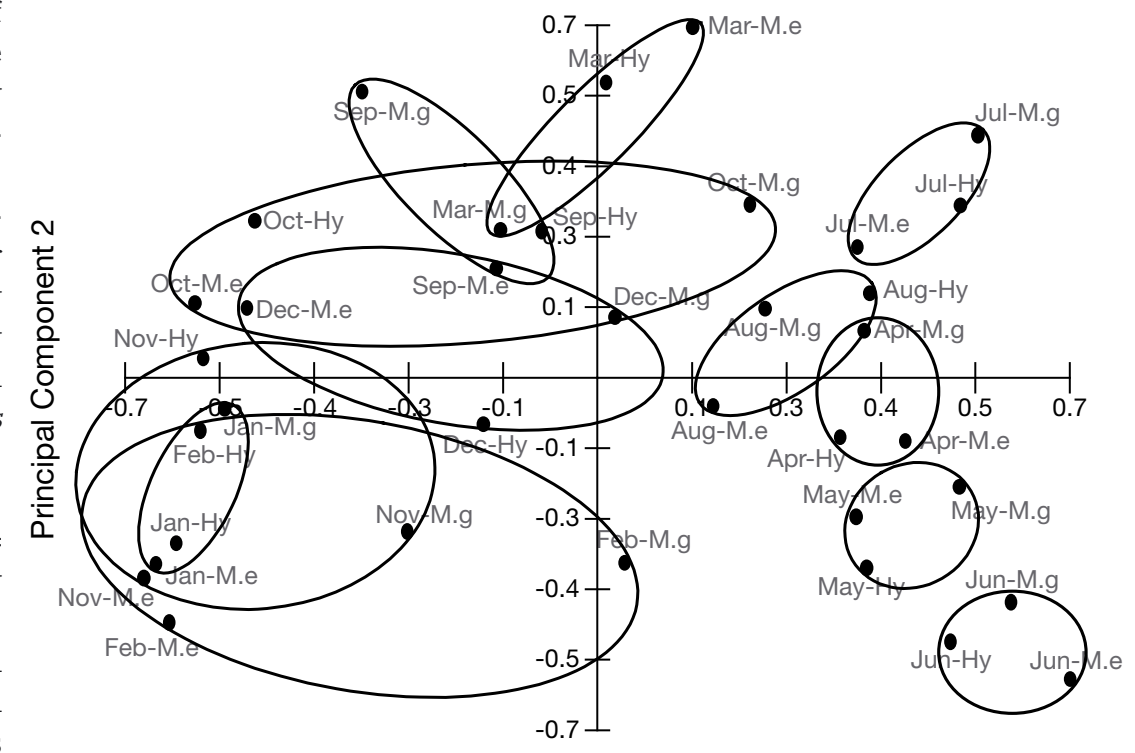

Principal Component 1

Fig. 9. Mytilus spp. PCA summarising mussel pathology and parasite data pooled by month and species (variability: Component $1=27 \%$, Component $2=$ $15 \%)$. M.e $=$ M. edulis, M.g = M. galloprovincialis, Hy = Hybrids. In general, greater differences can be seen between species during autumn and winter 
Table 4. Mytilus spp. PCA summarising pathologies and parasites observed in M. edulis, M. galloprovincialis and hybrid mussels in each month of study period. Bold: variables contributing most strongly to the 2 major components

\begin{tabular}{|lrr|}
\hline Pathology/Parasite & PC 1 & PC 2 \\
\hline Severe atrophy & -0.04 & $\mathbf{0 . 2 1}$ \\
Melanised bodies & $\mathbf{- 0 . 1 5}$ & $\mathbf{- 0 . 5 1}$ \\
Eosinophilic bodies & $\mathbf{0 . 4 7}$ & $\mathbf{- 0 . 2 5}$ \\
Degeneration & 0.06 & $\mathbf{0 . 6 8}$ \\
Rickettsia/chlamydia-like organisms (DG) & 0.06 & -0.07 \\
Rickettsia/chlamydia-like organisms (Gill) & -0.01 & 0.04 \\
Ancistrum mytili & $\mathbf{0 . 5 9}$ & 0.01 \\
Melanised aggregates & 0.01 & $\mathbf{- 0 . 2 8}$ \\
Haemocytic neoplasia & 0.00 & 0.00 \\
Inflammation & -0.06 & $\mathbf{0 . 1 3}$ \\
Granulocytoma & 0.02 & $\mathbf{- 0 . 1 4}$ \\
Digenean metacercaial stages & 0.07 & 0.02 \\
Haemocytic aggregates & 0.05 & $\mathbf{0 . 1 0}$ \\
Neoplasia & 0.00 & 0.00 \\
Marteilia sp. & 0.03 & -0.04 \\
M. intestinalis & $\mathbf{0 . 1 1}$ & 0.03 \\
Copepod & 0.08 & $\mathbf{0 . 1 7}$ \\
Haplosporidian & 0.04 & 0.08 \\
Pearl formations & 0.00 & 0.00 \\
Mussel protozoan & 0.06 & -0.05 \\
Bucephalid & 0.02 & 0.06 \\
Intersex/hermaphrodite & -0.01 & -0.03 \\
Coccidia & 0.00 & 0.00 \\
Gregarine & $\mathbf{0 . 1 6}$ & 0.01 \\
All gill ciliates & $\mathbf{0 . 5 9}$ & 0.01 \\
\hline
\end{tabular}

M. edulis and hybrids. In December, $M$. edulis showed a stronger negative association with Component 1 than M. galloprovincialis and hybrids. Some separation was also observed between $M$. edulis and hybrids in February and November in Component 2. Table 4 shows the variables contributing to Components 1 and 2, and the direction in which they act. Component 1 showed a positive association with eosinophilic bodies, Ancistrum mytili, gregarine infections and all gill ciliates. A negative association was observed between Component 1 and melanised bodies and Mytilicola intestinalis. Component 2 showed positive association with severe atrophy of the digestive diverticula, degeneration of the digestive diverticula, inflammation, haemocytic aggregates and copepods. Component 2 also showed a negative association with melanised bodies, eosinophilic bodies, melanised kidney aggregates and granulocytoma. Samples taken between April and August showed a positive association with Component 1 suggesting that eosinophilic bodies, all gill ciliates and A. mytili were most prevalent in these months. The above analyses appear to indicate that greater differences were present between species during autumn and winter than in the spring and summer.

\section{DISCUSSION}

We have provided baseline data for 29 health index parameters of mussels Mytilus edulis, Mytilus galloprovincialis and hybrids, from 2 estuaries in the UK. In addition to defining genotypic variation in mussels outside of previously defined hybrid zones for the Mytilus genus (Hilbish et al. 2002), this study has illustrated the extent of potential variation in mussel populations in terms of reproductive and physiological condition, and disease. Histopathology provides a mechanism to define these parameters and as such, is a valuable tool for inclusion in chemical and biological effects monitoring programmes using Mytilus spp., particularly where the natural seasonal variation in the population under study has not been clarified.

\section{Mussels in monitoring}

The mussel is viewed by the International Council for the Exploration of the Sea (ICES) Working Group for the Biological Effects of Contaminants (WGBEC) as an important monitoring organism, not least due to its ecological importance and its widespread geographic distribution covering the whole Oslo and Paris Commission (OSPAR) Programme for the Assessment and Control of Pollution in the Mediterranean (MEDPOL) and the Baltic Marine Environment Protection Commission (HELCOM) maritime areas. A range of biological effects techniques for mussels have been recommended by WGBEC for inclusion in the OSPAR Joint Assessment Monitoring Programme (JAMP) (JAMP 1998a,b), and a number of other methods are viewed as appropriate for integrated chemical and biological monitoring. Core methods include scope for growth, histopathology, metallothionein concentration, lysosomal stability and cholinesterase (AChE) inhibition (Widdows \& Salkeld 1992, Viarengo et al. 1997, Lowe \& Fossato 2000, Rickwood \& Galloway 2004, Marigómez et al. 2006). Additionally, with increasing emphasis on the application of 'omic' technologies in monitoring programmes, mussels once again appear suitably placed for future biomarker discoveries utilising these technologies (Manduzio et al. 2005, McDonagh et al. 2006, Hines et al. 2007a,b). In light of their increased usage as marine sentinels, it is important to consider the impact of our findings on the future application of biomarker technologies to field-collected animals and to provide recommendations for the collection of health parameter and species data to coincide with other biological and chemical measures. In this way it should be possible to dissociate markers of underlying health or condition from those associated with exposure to contaminants. 


\section{Effect of species}

We investigated the potential for species status to affect the accurate interpretation of histopathological data: i.e. Can different species collected from the same site be discriminated based upon histopathological criteria? Historically, a large proportion of published studies have utilised mussel populations believed to be composed of individuals of the species Mytilus edulis. However, detailed studies have shown that mussel populations along the west coast of the UK consist of a complex of $M$. edulis, $M$. galloprovincialis and a hybrid of the 2 (Skibinski et al. 1983, McDonald et al. 1991, Hilbish et al. 2002). We investigated a number of health index parameters in relation to species status from 1182 mussels over a 12 mo period using the Glu5' gene employing the ME15 and ME16 primer set to speciate individuals. While we only investigated a single allele marker, previous research has shown that the Glu-5' gene marker and allozyme loci used in previous studies of hybrid mussel, are strongly correlated (Hilbish et al. 2002). We found that both ADG rate and gonadal status was statistically different between separate species collected from within the Southampton Water site at specific times of the year. This suggests that even within the same sampling site, different species can display differential physiological phenotypes, thus, when comparing separate sites, species composition at those sites is a key consideration if data is to be reliably compared. Our data, particularly for $M$. edulis during reproductive quiescence, reinforces that of Hilbish et al. (2002) who showed that although the overall reproductive effort of both $M$. edulis and $M$. galloprovincialis was identical, reproductive strategy differed: spawning periods being asynchronous with M. edulis commencing gametogenesis and spawning earlier than M. galloprovincialis. Furthermore, M. edulis possessed a different storage cell strategy investing more heavily in their replenishment. This is thought to contribute to the strong intra-site viability selection, which acts within hybrid populations (Secor et al. 2001, Hilbish et al. 2003).

In most cases, the prevalence of pathogens and pathologies fluctuated throughout the year with differences only being observed between species and hybrids within individual months (Table 1, Fig. 9). PCA analysis did not reveal any overall differences in the annual trend of parasite burden and pathologies observed between species and hybrids. In general, greater differences were observed between species during autumn and winter (September to March) than during late spring and summer. Unfortunately, the numbers of each individual species present in sample sets collected from Southampton Water within given months were rarely equally distributed $(M$. edulis often representing a very small percentage of the population; Table 2). As a result, reliable statistical comparisons of disease prevalence between species and hybrids was not always possible. Future studies of this nature should ensure that statistically significant numbers of all species are collected in order to accurately assess effect of species on health parameters. In the present study, only prevalence data for disease and pathology was recorded. We recommend that future investigations of this type should also aim to incorporate data on the severity of the pathologies encountered, allowing a more rigorous statistical analysis of health data.

Since disease status and physiological condition in molluscs significantly affect each other (Elston et al. 1988, Mix 1988, Winstead \& Couch 1988, Bower 1992, Bucke 1993, Mortensen et al. 2005) and likely the functional response of mussels to environmental stressors (e.g. exposure to contaminants), it is important to further investigate the relationship between species and disease. It has previously been reported that parasitism differentially affects Mytilus edulis and M. galloprovincialis collected from the same site. The pea crab Pinnotheres pisum appears to preferentially infect M. galloprovincialis over M. edulis (Seed 1969) while the trematode Prosorhynchus squamatus has been detected at higher prevalence in $M$. edulis than in $M$. galloprovincialis (Coustau et al. 1991). With respect to contaminant exposure, Lobel et al. (1990) discovered higher concentrations of metals present in Mytilus trossulus compared to levels in $M$. edulis of the same size range. It was thought that this could be related to the slower growth rate of $M$. trossulus. In light of the current study and those described, we suggest that species classification should be considered when using mussels for comparative site assessments of environmental health status, particularly when sites are being investigated for the first time. In this way, those responsible for providing advice on the health of aquatic environments can ensure that reference and exposed populations are truly comparative. The magnitude of the species effect may be more fully understood when tissues are analysed using 'omic' technologies. For example, studies using 2D electrophoresis coupled with MALDI-TOF (Matrix Assisted Laser Desorption/Ionisation-Time of Flight) to investigate pure and hybrid populations of $M$. edulis and $M$. galloprovincialis have identified differentially expressed proteins representing various function classes including structural proteins, stress response proteins and proteins associated with storage and energy production (Fuentes et al. 2002, López et al. 2002). In these instances, variations in gene, protein or metabolite expression between species could potentially confuse the signal for true biomarkers of exposure effect if species identification 
data is not used to inform sample groupings (see Stentiford et al. 2005, Ward et al. 2006, Hines et al. 2007a).

\section{Effects of season}

Aquatic poikilotherms including mussels undergo pronounced seasonal cycles relating to their physiological and reproductive condition. This and previous studies have shown how ADG and reproductive status are dynamic variables that depend not only upon genetically controlled cycles but also upon those imposed by the environment (e.g. season) and by exogenous factors such as disease (highlighted within this study). In this way, mussels sampled at different times of the year exhibit variable life history profiles that must be taken into account when attempting to compare biomarker data from groups of animals collected during different seasons or from different sites. When using markers that can change relatively quickly during certain times of year (such as ADG rate), it should be considered whether sampling within these windows would introduce highly variable datasets. Other than ADG rate and gonadal status, seasonal changes were observed in the prevalence of Ancistrum mytili and haemocytic aggregates of the gonad. No similar seasonal changes were seen in the prevalence of other health index parameters, however fluctuations in trend were observed throughout the year. In several of these cases fluctuations were similar between sites (melanised kidney aggregates, digestive diverticula degeneration, inflammation, granulocytoma, Mytilicola intestinalis). This may suggest that the factors influencing one site may also be the same for another: i.e. environmental influences, normal cell turnover, gonadal maturation and resorption. Taken together, we recommend that the design of biological effects monitoring programs must carefully consider likely changes in those variables intended for measurement throughout the season (Rickwood \& Galloway 2004).

\section{Effect of pathogens, pathology and condition}

Given the wide range of pathogens discovered in mussels from the Exe estuary and Southampton Water, there is potential for biomarker data to be affected by these conditions, once again skewing true interpretation of biological effects data. Several of the pathogens observed in our study affect cell morphology and tissue architecture, leading to altered function especially during heavy infections. Infections with Steinhausia mytilovum and bucephalids can cause cessation of gonadal maturation often leading to castration and a reduced ADG rate. Heavy infection with Marteilia sp. and haplosporidians leads to considerable displacement of the digestive epithelium with individual parasites occupying much of the cytoplasm of the digestive cells. In the context of biomarker assessment, histopathological data pertaining to disease or physiological condition can be used to inform sample groupings, including the selected use of animals of a particular reproductive or physiological condition, or those displaying the absence of a particular disease state (that in itself may be expected to affect the accurate measurement of the biomarker in question) (Stentiford et al. 2005, Ward et al. 2006). In addition, we recommend that field-collected animals utilised in laboratory studies (e.g. measurement of scope for growth) should be prepared for histopathology post-experiment to allow for potential effects of differential condition, reproductive status and disease to be discounted from any measured differences in growth between animals from control and exposed sites.

\section{CONCLUSIONS}

This study has identified variables inherent within field-sampled marine sentinels that may prevent robust site-to-site comparisons. In light of the increased usage of mussels as biological effects monitoring organisms, it is important to consider the impact of our findings on the future application of biomarker technologies to field-collected animals. We therefore recommend that collection of basic life history data should coincide with the collection of biomarker and chemistry information wherever possible. Future studies should ensure that the species status of test populations is known and that statistically significant numbers of each species is collected in order to assess any inter-species variability of response within site. This is particularly important where new sites (with unknown species profiles) are being investigated. Sampling season must also be carefully considered, particularly when sites from different latitudes are being compared. Taken together, we recommend that biological effects monitoring programs must be carefully designed to consider likely natural changes that occur in sentinels throughout a normal season. Histopathology data for individual mussels can inform sample groupings for downstream 'omic' or other biomarker analyses, thereby acting as a baseline against which true effects of historic exposure can be assessed.

Acknowledgments. The authors acknowledge the support of the Department for Environment, Food and Rural Affairs (Defra) under contract number F1166 and CDEP 84/5/312. All work and procedures were carried out in accordance with current UK legislation. 


\section{LITERATURE CITED}

Akberali HB, Earnshaw MJ, Marriott KRM (1985) The action of heavy metals on the gametes of the marine mussel, Mytilus edulis (L.). II. Uptake of copper and zinc and their effect on respiration in the sperm and unfertilised egg. Mar Environ Res 16:37-59

Auffret M (1988) Histopathological changes related to chemical contamination in Mytilus edulis from field and experimental conditions. Mar Ecol Prog Ser 46:101-107

Bayne BL (1976) Watch on mussels. Mar Pollut Bull 7:217-218

Bower SM (1992) Diseases and parasites of mussels. In: Gosling E (ed) The mussel Mytilus: ecology, physiology, genetics and culture. Developments in Aquaculture and Fisheries Science, 25. Elsevier Science, Amsterdam, p 543-563

Bucke D (1993) Aquatic pollution: effects on the health of fish and shellfish. Parasitology 106:S25-S37

Calabrese A, MacInnes JR, Nelson DA, Greig RA, Yevich PP (1984) Effects of long-term exposure to silver or copper on growth, bioaccumulation and histopathology in the blue mussel Mytilus edulis. Mar Environ Res 11:253-274

Coustau C, Renaud F, Maillard C, Pasteur N, Delay B (1991) Differential susceptibility to a trematode parasite among genotypes of the Mytilus edulis / galloprovincialis complex. Genet Res 57:207-212

Davey JT (1989) Mytilicola intestinalis (Copepoda: Cyclopoidia): a ten year survey of infested mussels in a Cornish estuary, 1978-1988. J Mar Biol Assoc UK 69:823-836

Dimitriadis VK, Koukouzika N (2003) Effect of sampling procedures, transportation stress and laboratory maintenance on the structure and function of the digestive gland epithelium of the mussel Mytilus galloprovincialis. Mar Biol 142:915-924

Elston RA, Kent ML, Drum AS (1988) Progression, lethality and remission of hemic neoplasia in the bay mussel Mytilus edulis. Dis Aquat Org 4:135-142

Figueras AJ, Jardon CF, Caldas JR (1991) Diseases and parasites of mussels (Mytilus edulis, Linneaus, 1758) from two sites on the east coast of the United States. J Shellfish Res 10:89-94

Fuentes J, López JL, Mosquera E, Vázques J, Villalba A, Álvarez G (2002) Growth, mortality, pathology conditions and protein expression of Mytilus edulis and M. galloprovincialis crosses cultured in the Ría de Arousa (NW of Spain). Aquaculture 213:233-251

Galloway TS, Millward N, Browne MA, Depledge MH (2002) Rapid assessment of organophosphorous/carbamate pesticide exposure in the bivalve mollusc Mytilus edulis using combined esterase activities as biomarkers. Aquat Toxicol 61:169-180

Goldberg ED, Bertine KK (2000) Beyond Mussel Watch—new directions for monitoring marine pollution. Sci Total Environ 247:165-174

Goldberg ED, Bowen VT, Farrington JW, Harvey G and others (1978) The Mussel Watch. Environ Conserv 5:101-125

Granmo A (1995) Mussels as a tool in impact assessment. Phuket Mar Biol Cent Spec Publ 15:215-220

Hilbish TJ, Carson EW, Plante JR, Weaver LA, Gilg MR (2002) Distribution of Mytilus edulis, M. galloprovincialis, and their hybrids in open-coast populations of mussels in southwestern England. Mar Biol 140:137-142

* Hilbish TJ, Timmons J, Agrawal V, Schneider KR, Gilg MR (2003) Estuarine habitats protect hybrid mussels from selection. J Exp Mar Biol Ecol 292:177-186

Hines A, Oladiran G, Bignell J, Stentiford GD, Viant MR (2007a) Direct sampling of organisms from the field and knowledge of their phenotype: key recommendations for environmental metabolomics. Environ Sci Technol 41: 3375-3381

* Hines A, Yeung WH, Craft J, Brown M and others (2007b) Comparison of histological, genetic, metabolomic and lipid-based methods for sex determination in marine mussels. Anal Biochem 369:175-186

Inoue K, Herbert Waite J, Matsuoka M, Odo S, Harayama S (1995) Interspecific variations in adhesive protein sequences of Mytilus edulis, M. galloprovincialis and $M$. trossulus. Biol Bull 189:370-375

JAMP (Joint Assessment and Monitoring Programme) (1998a) Guidelines for general biological effects monitoring. OSPAR Commission, London

JAMP (Joint Assessment and Monitoring Programme) (1998b) Guidelines for contaminant specific biological effects monitoring. OSPAR Commission, London

Kluytmans JH, Brands F, Zandee DI (1988) Interactions of cadmium with the reproductive cycle of Mytilus edulis L. Mar Environ Res 24:189-192

* Lobel PB, Belkhode SP, Jackson SE, Longerich HP (1990) Recent taxonomic discoveries concerning the mussel Mytilus: implications for biomonitoring. Arch Environ Contam Toxicol 19:508-512

* López J, Marina A, Vázquez J, Alvarez G (2002) A proteomic approach to the study of the marine mussels Mytilus edulis and M. galloprovincialis. Mar Biol 141:217-223

Lowe DM, Fossato VU (2000) The influence of environmental contaminants on lysosomal activity in the digestive cells of mussels (Mytilus galloprovincialis) from the Venice Lagoon. Aquat Toxicol 48:75-85

Lowe DM, Pipe RK (1987) Mortality and quantitative aspects of storage cell utilization in mussels, Mytilus edulis, following exposure to diesel oil hydrocarbons. Mar Environ Res 22:243-251

*Manduzio H, Cosette P, Gricourt L, Jouenne T and others (2005) Proteome modifications of blue mussel (Mytilus edulis L.) gills as an effect of water pollution. Proteomics 5:4958-4963

*Marigómez I, Soto M, Cancio I, Orbea A, Garmendia L, Cajaraville MP (2006) Cell and tissue niomarkers in mussel, and histopathology in hake and anchovy from Bay of Biscay after the Prestige oil spill (Monitoring Campaign). Mar Pollut Bull 53:287-304

*McDonagh B, Tyther R, Sheehan D (2006) Redox proteomics in the mussel, Mytilus edulis. Mar Environ Res 62: S101-S104

*McDonald JH, Seed R, Koehn RK (1991) Allozymes and morphometric characters of three species of Mytilus in the Northern and Southern Hemispheres. Mar Biol 111: $323-333$

Mix MC (1988) Shellfish diseases in relation to toxic chemicals. Aquat Toxicol 11:29-42

*Moore MN (1990) Lysosomal cytochemistry in marine environmental monitoring. Histochem J 22:187-191

*Moore MN, Livingstone DR, Widdows J, Lowe DM, Pipe RK (1987) Molecular, cellular and physiological effects of oilderived hydrocarbons on molluscs and their use in impact assessment. Philos Trans R Soc Lond B Biol Sci 316: $603-623$

* Mortensen S, Harkestad LS, Stene R, Renault T (2005) Picoeucaryot alga infecting blue mussel Mytilus edulis in southern Norway. Dis Aquat Org 63:25-32

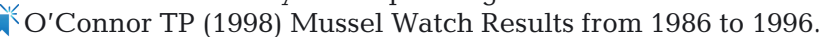
Mar Pollut Bull 37:14-19

Olsson B, Bradley BP, Gilek M, Reimer O, Shepard JL, Tedengren M (2004) Physiological and proteomic responses in 
Mytilus edulis exposed to PCBs and PAHs extracted from Baltic Sea sediments. Hydrobiologia 514:15-27

Powell EN, Barber RD, Kennicutt MC II, Ford SE (1999) Influence of parasitism in controlling the health, reproduction and PAH body burden of petroleum seep mussels. DeepSea Res I 46:2053-2078

Rasmussen L (1982) Light microscopical studies of the acute toxic effects of $\mathrm{N}$-Nitrosodimethylamine on the marine mussel, Mytilus edulis. J Invertebr Pathol 39:66-80

Rasmussen LPD (1986) Virus-associated granulocytoma in the marine mussel Mytilus edulis, from three sites in Denmark. J Invertebr Pathol 48:117-123

* Rickwood CJ, Galloway TS (2004) Acetylcholinesterase inhibition as a biomarker of adverse effect. A study of Mytilus edulis exposed to the priority pollutant chlorfenvinphos. Aquat Toxicol 67:45-56

Robledo JAF, Santarém MM, Figueras A (1994) Parasite loads of rafted blue mussels (Mytilus galloprovincialis) in Spain with special reference to the copepod, Mytilicola intestinalis. Aquaculture 127:287-302

Rosenblum ES, Viant MR, Braid BM, Moore JD, Friedman CS, Tjeerdema RS (2005) Characterizing the metabolic actions of natural stresses in the california red abalone, Haliotis rufescens using ${ }^{1} \mathrm{H}$ NMR metabolomics. Metabolomics 1: 199-209

Rosenblum ES, Tjeerdema RS, Viant MR (2006) Effects of temperature on host-pathogen-drug interactions in red abalone, Haliotis rufescens, determined by ${ }^{1} \mathrm{H}$ NMR metabolomics. Environ Sci Technol 40:7077-7084

Salazar MH, Salazar SM (1995) In situ bioassays using transplanted mussels. I. Estimating chemical exposure and bioeffects with bioaccumulation and growth. In: Hughes JS, Biddinger GR, Mones E (eds) Environmental toxicology and risk assessment, Vol 3. STP 2118, American Society for Testing and Materials, Philadelphia, PA, p 216-241

Secor CL, Day AJ, Hilbish TJ (2001) Factors influencing differential mortality within a marine mussel (Mytilus spp.) hybrid population in southwestern England: reproductive effort and parasitism. Mar Biol 138:731-739

Seed R (1969) The incidence of pea crab Pinnotheres pisum in two types of Mytilus (Mollusca: Bivalvia) from Padstow, south west England. J Zool 158:413-420

Seed R (1976) Ecology. In: Bayne BL (ed) Marine mussels, their ecology and physiology. International Biological Programme 10. Cambridge University Press, Cambridge, p 13-65

Shepard JL, Olsson M, Tedengren M, Bradley BP (2000)

Initial editorial responsibility: Howard Browman,

Storebø, Norway (until November 5, 2007)

Final editorial responsibility: Matthias Seaman,

Oldendorf/Luhe, Germany
Protein expression signatures identified in Mytilus edulis exposed to PCBs, copper and salinity stress. Mar Environ Res 50:337-340

K Skibinski DOF, Beardmore JA, Cross TF (1983) Aspects of the population genetics of Mytilus (Mytilidae; Mollusca) in the British Isles. Biol J Linn Soc 19:137-183

Stentiford GD, Viant MR, Ward DG, Johnson PJ and others (2005) Liver tumors in wild flatfish: a histopathological, proteomic, and metabolomic study. Omics J Integr Biol 9(3):281-299

Sunila I (1984) Copper- and cadmium- induced histological changes in the mantle of Myituls edulis L. (Bivalvia). Limnologica 15:523-527

Svärdh L (1999) Bacteria, granulocytomas, and trematode metacerariae in the digestive gland of Mytilus edulis: seasonal and interpopulation variation. J Invertebr Pathol 74:275-280

Viant MR, Rosenblum ES, Tjeerdema RS (2003) NMR-Based metabolomics: A powerful approach for characterizing the effects of environmental stressors on organism health. Environ Sci Technol 37:4982-4989

*Viarengo A, Ponzano E, Dondero F, Fabbri R (1997) A simple spectrophotometric method for metallothionein evaluation in marine organisms: an application to mediterranean and antarctic molluscs. Mar Environ Res 44:69-84

Ward DG, Wei W, Cheng Y, Billingham LJ and others (2006) Plasma proteome analysis reveals the geographical origin and liver tumor status of dab (Limanda limanda) from UK marine waters. Environ Sci Technol 40:4031-4036

Widdows J, Donkin P (1992) Mussels and environmental contaminants: bioaccumulation and physiological aspects. In: Gosling E (ed) The mussel Mytilus: ecology, physiology, genetics and culture. Developments in Aquaculture and Fisheries Science, 25. Elsevier Science, Amsterdam, p 383-464

Widdows J, Salkeld P (1992) Practical procedures for the measurement of scope for growth. MAP Tech Rep Ser 71: $147-172$

Widdows J, Donkin P, Staff FJ, Matthiessen P and others (2002) Measurement of stress effects (scope for growth) and contaminant levels in mussels (Mytilus edulis) collected from the Irish Sea. Mar Environ Res 53:327-356

Winstead JT, Couch JA (1988) Enhancement of protozoan pathogen Perkinsus marinus infections in American oysters Crassostrea virginica exposed to the chemical carcinogen n-nitrosodiethylamine (DENA). Dis Aquat Org 5:205-213

Submitted: May 21, 2007; Accepted: January 15, 2008 Proofs received from author(s): February 1, 2008 